\title{
MOLECULAR EPIDEMIOLOGY OF Staphylococcus aureus ISOLATES AT DIFFERENT SITES IN THE MILK PRODUCING DAIRY FARMS
}

\section{Viviane Souza ${ }^{1}$, Antonio Nader Filho ${ }^{2}$, Poliana de Castro Melo ${ }^{2}$, Guilherme Moraes Ferraudo ${ }^{3}$, Antônio Sérgio Ferraudo ${ }^{4}$, Sandra de Oliveira Conde ${ }^{2}$, Flavio Augusto Fogaça Junior²}

${ }^{1}$ Embrapa Caprinos e Ovinos, Sobral, CE, Brasil; ${ }^{2}$ Departamento de Medicina Veterinária Preventiva e Reprodução Animal, Faculdade de Ciências Agrárias e Veterinárias, Universidade Estadual Paulista, Jaboticabal, SP, Brasil; ${ }^{3}$ Genética e Melhoramento de Plantas, Universidade Estadual Paulista, Jaboticabal, SP, Brasil; ${ }^{4}$ Departamento de Ciências Exatas, Faculdade de Ciências Agrárias e Veterinárias, Universidade Estadual Paulista, Jaboticabal, SP, Brasil;

Submitted: March 21, 2011; Returned to authors for corrections: May 09, 2011; Approved: June 07, 2012.

\begin{abstract}
The epidemiological relationships between isolated Staphylococcus aureus strains in milk samples of dairy cows, reagent to California Mastitis Test, individual and group milk was demonstrated in different sites of the production fluxogram, in 12 milk-producing farms in the Gameleira region, municipality of Sacramento MG Brazil, so that localization and transmission modes may be identified. Two hundred and forty-four strains out of 446 samples collected at several sites were isolated and bio-chemically characterized as coagulase-positive staphylococcus. Specific chromosome DNA fragment of the species Staphylococcus aureus was amplified to 106 strains and 103 underwent (PFGE). Samples' collection sites with the highest isolation frequency of Staphylococcus aureus strains comprised papillary ostia (31.1\%), CMT-reagent cow milk (21.7\%), mechanical milking machines’ insufflators (21,7\%), milk in milk pails (6.6\%) and the milk in community bulk tanks (5.6\%). Genetic heterogeneity existed among the isolated 103 Staphylococcus aureus strains, since 32 different pulse-types were identified. Pulse-type 1 had the highest similarity among the isolated strains within the different sites of the milk-production fluxogram. Highest occurrence of pulsetype 1 isolates of Staphylococcus aureus strains was reported in samples collected from the papillary ostia (10.6\%), followed by milk samples from CMT-reagent dairy cows (5.8\%) and mechanical milking machine insufflators (3.8\%). The above shows the relevance of these sites in the agents' transmission mechanism within the context of the farms investigated.
\end{abstract}

Key words: mastitis; Staphylococcus aureus, bulk tank, PCR, PFGE.

\section{INTRODUCTION}

Mastitis is one of the diseases which causes high liabilities in milk production owing to decrease in quantity and quality of milk and milk products, medicine costs, increase in labor expenses and in the time wasted during milk discarding after

*Corresponding Author. Mailing address: Embrapa Caprinos e Ovinos, Sobral-CE.; E-mail: vivianesouzavet@yahoo.com.br 
treatment, up to the total elimination of antibiotic residues employed $(2,16)$.

Among etiological agents in mastitis, Staphylococcus aureus has a high prevalence in the cattle under analysis. The main infection sources are animals with the four-partitioned udders infected by $S$. aureus and with contaminated udder skin and teats. Moreover, the insufflators of milking machines are the chief means of infection transmission (12).

The determination of the origin of the organisms involved in the etiology of bovine mastitis is highly relevant from the epidemiological point of view. In such a context, the precise characterization of pathogens becomes mandatory for the detection of transmission methods and infection sources. It also provides monitoring of the dissemination of bacterial strains among animal populations (7).

According to Prata et al. (13), molecular characterization should be enhanced for the correct identification of microorganism species involved in mastitis and for the identification of genes which cause virulence in the main pathogens. In fact, they will help in epidemiological studies and will provide the tracing of pathogens throughout the milk production chain.

The characterization of the genetic diversity of $S$. aureus isolated from milk-producing cattle is highly important for a better understanding of the pathogen's dispersion pattern. Such information may be of great help in the elaboration of more efficient strategies that decrease infection cases. Through molecular profiles, genetic relationships among different clones may be inferred, genetic flow may be detected and infection dispersion routes in cattle may be traced (6).

It seems that, among genotype analysis techniques, the Pulsed Field Gel Electrophoresis (PFGE) of fragments obtained by micro-restriction is the most sensitive method. It may actually detect genetic variations among phylogenetically and epidemiologically related bacterial isolates, including $S$. aureus (20).

According to Tenover et al. (18), PFGE technique is the most discriminatory typing tool for $S$. aureus. In fact, it is not merely used to detect smaller genetic variations among epidemic strains, but it has proved to be an excellent method for the establishment of clonal relationships in epidemiological and molecular studies.

Consequently, current investigation shall establish the epidemiological relationship among Staphylococcus aureus strains in milk samples of CMT-reagent dairy cows, in individual and community bulk tank, from 12 milk-producing farms and at different sites of the production fluxogram so that the transmission loci and modes could be identified.

\section{MATERIALS AND METHODS}

\section{Samples}

Two hundred and twenty-two cows from 12 farms in Sacramento MG Brazil undertook the California Mastitis Test (CMT) between January and April 2009. A total of 101 samples of milk from the udders of CMT-reagent dairy cows from 12 milk-producing farms, and 15 samples from the milk in two bulk tanks, were collected in sterilized test tubes, according to National Mastitis Council's protocols. In addition, 101 samples were collected from papillary ostia, 25 samples of clean milk cans, 32 samples of pails, sieves and surface of the expansion bulk tank, 104 samples from insufflators of mechanical milking machines, 22 samples of milker's hands and 33 samples water used on the farm and in community bulk tanks, totaling 446 samples. The sampling procedures followed the recommendations of Apha (1), Harmon et. al. (5) and McDonald et al. (10).

The samples were transported in isothermal boxes, with ice, to the Laboratory of Microbiological Analysis of Animalderived Food and Water, Department of Preventive Veterinary Medicine and Animal Reproduction, FCAV, UNESP, Jaboticabal SP Brazil.

\section{Isolation and identification}

Milk samples derived from the udders of CMT-reagent dairy cows and milk samples from milk cans from farms and 
community bulk tanks were directly spread plate on petri dishes containing Baird-Parker agar (Himedia ${ }^{\circledR}$, Mumbai, India), and incubated at $37^{\circ} \mathrm{C}$ for 24 to 48 hours. Samples from papillary ostia, insufflators, milk cans, pails, sieves, tube surfaces and milker's hands were sown in Baird-Parker agar with cotton swabs used in sample collection, and incubated at $37^{\circ} \mathrm{C}$ for 24 to 48 hours.

Further, 3 to 5 colonies were sown in inclined tubes with nutrient agar and incubated at $37^{\circ} \mathrm{C}$ during 24 hours. After incubation, Gram's method was made for morphological analysis of cultures. Cultures, in the form of Gram-positive cocci and grouped in bunches, underwent catalase, free coagulase and acetoin production (VP) tests (MRVP broth Oxoid®, Hampshire, UK) (8).

\section{Molecular identification of $\boldsymbol{S}$. aureus strains}

Staphylococcus aureus was molecularly characterized by the amplification of chromosome DNA fragments, specific to these microorganisms, according to protocols by Martineau et al. (9), in all strains with Gram-positive cocci, grouped in bunches, and positive to catalase, coagulase and VogesProskauer tests. DNA was extracted from the isolated strains using Kit Invitek ${ }^{\circledR}$, - Extraction of Genomic Material, containing DNA extraction protocol for Gram-positive bacteria, lyse, extraction, washing solutions and purification columns.

PFGE followed protocol by McDougal et al. (11). The classification of group pulsetypes was produced by a dendrogram made from the grouping analysis hierarchical method (4), employing the similarity pattern between pulsetypes, Jaccard's coefficient and Ward's method to linkage the groups (17). Cluster analysis was processed by free software R, version 2.11.1, and classification of pulsetypes was undertaken by dendrogram analysis, according to Tenover et al. (19). Analyses were done at the Department of Exact Sciences of the Agrarian and Veterinarian University, UNESP, Jaboticabal, SP, Brazil.

\section{RESULTS AND DISCUSSION}

Two hundred and forty-four strains of coagulase positive staphylococci were isolated and identified from the 446 samples collected from several sites of the milk fluxogram. They underwent amplification of chromosome DNA fragments specific to the Staphylococcus aureus strain. DNA fragment was amplified in 106 samples from among the 244 coagulasepositive staphylococci strains.

When PFGE was under way, three S. aureus strains failed to reach bacterial concentration required for the test. Nevertheless, PFGE was done in 103 S. aureus strains.

Following grouping analysis method, S. aureus strains analyzed in 32 pulsetypes were classified. Since a great number of pulsetypes were registered, a high genetic heterogeneity among isolates was reported. The above is similar to results by Ferreira (3) who, in his research in Nova Odessa SP Brazil, obtained 39 pulsetypes from 245 S. aureus strains isolated from milk in mastitis cases, papillary ostia and mechanical milking machine insufflators.

Lange et al. (7) researched 66 S. aureus strains isolated from the milk of cows with mastitis in southern Brazil and reported 33 distinct pulsetypes and the same DNA restriction pattern in $15.1 \%$ of the samples.

According to Roberson et al. (14), high variability among phenotypic and genotypic patterns may be due to the different sites in which the $S$. aureus has been found, since the microorganisms may be isolated from the milk of cows with clinical and sub-clinical mastitis, from the teats' skin surface, from the insufflators of the milking machines and from the milker.

Current analysis shows that pulsetype 1 was predominant, with $25.2 \%$ (26) of typed strains, followed by patterns 15,3 , 4, 11 and 25, respectively with 5.8\% (6), 3.8\% (4), 3.8\% (4), $3.8 \%(4)$ and $3.8 \%(4)$.

Since pulsetype 1 had the highest similarity among isolated $S$. aureus strains at different sites of the milk production fluxogram, the agent's dissemination among the 
several farms was evident. Therefore, isolates of the same genetic profile identified in the insufflators, in the papillary ostia and in the milk reveal the relevance of milking machines as a transmission mode of mastitis’s etiological agent.

The highest distribution of pulsetype 1 of $S$. aureus strains was reported in the papillary ostia, followed by milk from CMT-reagent dairy cows and by insufflators, with 11 (10.6\%), 6 (5.8\%) and 4 (3.8\%) respectively. These data reveal the importance of these sites within the agent's transmission mechanism in the farms under analysis. Results also show that routine hygiene procedures during milking, cleaning and the disinfection of utensils and equipments on the farms analyzed were not undertaken properly, not used since no cleaning procedure.

Pulsetype 1, which occurred in 8 (66.6\%) of the 12 farms investigated, was found in isolates in papillary ostia, in milk from CMT-reagent dairy cows, in milk from milk cans used on the farms, in insufflators of milking machines and in the milk stored in community bulk tanks.

In an epidemiological-molecular study associated with bovine mastitis on milk-producing farms in the states of São Paulo and Pernambuco, Brazil, Santos (15) reported that the isolation of $S$. aureus, belonging to the same genetic profile, in insufflators and in milk samples, reveals the milking machines' role as possible transmission modes of bovine mastitis in the cattle herd. The same author also remarked that the udder's skin is also another mastitis transmission vehicle.

Reporting on the maintenance and clonal dissemination of certain pulsetypes identified in analyzed samples, Ferreira (3) insists that the occurrence of $S$. aureus strains with the same pulsetypes in a single collection shows an epidemiological relationship between infection sources and transmission modes in milk samples, papillary ostia and insufflators of milking machines.

In current study, S. aureus dissemination on different farms may be due to their closeness and to the community status of the milk refrigerating tank. When milk was taken for storage, the milk cans were mechanically cleansed on the spot where community bulk tanks were installed and thus the dissemination of microorganisms was highly favorable.

The occurrence of $S$. aureus shows the importance of the agents' diagnosis in cattle mastitis and its identification provides a working policy for more rational and effective control programs. Thus, the control of the disease's occurrence not only decreases treatment costs but also establishes favorable conditions for the improvement of milk quality in the region.

\section{ACKNOWLEDGEMENTS}

The authors gratefully acknowledge the financial support of Conselho Nacional de Desenvolvimento Científico e Tecnológico (CNPq), and Fundação de Amparo à Pesquisa do Estado de São Paulo (FAPESP), Brazil.

\section{REFERENCES}

1. American Public Health Association. Committee on Microbiological Methods for Foods. (2001). Compendium of methods for the microbiological examination of foods. 3. ed. Washington: American Public Health Association.

2. Costa, E.O.; Sá, R.; Ponce, H.; Watanabe, E.T.; Valle, C.R. (1999). Avaliação da terapia de mastite clínica: eficácia terapêutica medida em número de dias em tratamento. Napgama, 2 (2), 10-14.

3. Ferreira, L.M. (2008). Epidemiologia molecular aplicada ao monitoramento de estirpes de Staphylococcus aureus envolvidas em casos de mastite bovina. Jaboticabal, Brasil, 88p. (D.Sc. Dissertation. Universidade Estadual Paulista, Faculdade de Ciências Agrárias e Veterinárias. UNESP Jaboticabal).

4. Hair, J.F.; Anderson, R.E.; Tatham, R.L.; Black, W. (2005). Análise multivariada de dados. Bookman, Porto Alegre.

5. Harmon, R.J.; Eberhart, R.J.; Jasper, D.E.; Langlois, B.E.; Wilson, R.A. (1990). Microbiological procedures for the diagnosis of bovine udder infection. National Mastitis Council, Arlington.

6. Kapur, V.; Sischo, W.M.; Greer, R.S.; Whittam, T.S.; Musser, J.M. (1995). Molecular population genetic analysis of Staphylococcus aureus recovered from cows. J. Clin. Microbiol., 33 (2), 376-380.

7. Lange, C.; Cardoso, M.; Senczek, D.; Schwarz, S. Molecular subtyping of Staphylococcus aureus isolates from cases of bovine mastitis in Brazil (1999). Vet. Microbiol., 67 (2), 127-141.

8. Mac Faddin, J.F. (1976). Biochemical tests for identification of medical 
bacteria. Williams \& Wilkins Co. Baltimore.

9. Martineau, F.; Picard, F.J.; Roy, P.H.; Ouellette, M.; Bergeron, M.G. (1998). Species-specific and ubiquitous-DNA-based assays for rapid identification of Staphylococcus aureus. J. Clin. Microbiol., 36 (3), 618623.

10. McDonald, J.; Kinsel, M. L.; Adams, D. S.; Darlington, R.L. (1993).Studying the effects of backflushing milking units. Vet. Med., 88(4), 382-386.

11. McDougal, L.K.; Steward, C.D.; Killgore, G.E.; Chaitram, J.M.; McAllister, S.K.; Tenover, F.C. (2003). Pulsed-Field Gel Electrophoresis Typing of Oxacillin-Resistant Staphylococcus aureus isolates from the United: Establishing a National Database. J. Clin. Microbiol., 41 (11), 5113-5120.

12. Myllys, V.; Ridell, J.; Björkroth, J.; Biese, I.; Pyörälä, S. (1997). Persistence in bovine mastitis of Staphylococcus aureus clones as assessed by random amplified polymorphic DNA analysis, ribotyping and biotyping. Vet. Microbiol., 57 (1-2), 245-251.

13. Prata, M.C.A.; Brito, J.R.F.; Brito, M.A.V.P.; Oliveira, V.M.; Souza, G.N.; Lange, C.C.; Ribeiro, A.C.C.L.; Carvalho, A.C.; Arcuri, E.F.; Silva, M.R.; Faria, C.G. (2006). Saúde Animal. In: Santos, C.A., Carvalho, L.A., Campos, O.F., Arcuri, P.B.(eds). Embrapa Gado de Leite: 30 anos de pesquisa e conquistas para o Brasil. Juiz de Fora, Minas Gerais, p.103-122.

14. Roberson, J.R.; Fox, L.K.; Hancock, D.D.; Gay, J.M.; Besser, T.E. (1994). Ecology of Staphylococcus aureus isolated from various sites on dairy farms. J. Dairy Sci., 77 (11), 3354-3364.

15. Santos, F.G.B. (2009). Estudo epidemiológico molecular e de fatores de virulência de Staphylococcus aureus associados à mastite bovina em propriedades de exploração leiteira dos estados de São Paulo e Pernambuco. São Paulo, Brasil, 45p. (D.Sc. Dissertation. Instituto de Ciências Biomédicas. USP).

16. Santos, M.V. (2003). Impacto econômico da mastite bovina. A Hora Vet., 22 (131), 46-50.

17. Sneath, P.H.A.; Sokal, R.R. (1973). Numerical taxonomy the principles and practice of numerical classification. W. H. Freeman Co. San Francisco.

18. Tenover, F.C.; Arbeit, R.D.; Goering, R.V. (1997). How to Select and Interpret Molecular Strain Typing Methods for Epidemiological Studies of Bacterial Infections: A Review for Healthcare Epidemiologists. Infect. Control. Hosp. Epidemiol., 18 (6), 426-439.

19. Tenover, F.C.; Arbeit, R.D.; Goering, R.V.; Mickelsen, P.A.; Murray, B.E.; Persing D.H.; Swaminathan, B. (1995). Interpreting chromosomal DNA restriction patterns produced by pulsed-field gel electrophoresis: criteria for bacterial strain typing. J. Clin. Microbiol., 33 (9), 2233-2239.

20. Zadoks, R.N.; Leeuwen, W.B.; Kreft, D.; Fox, L.K.; Barkema, H.W.; Schukken, Y.H.; Belkum, A. (2002). Comparison of Staphylococcus aureus isolates from bovine and human skin, milking equipment, and bovine milk by phage typing, Pulsed-Field Gel Electrophoresis, and Binary Typing. J. Clin. Microbiol., 40 (11), 3894-3902. 